\title{
Commentary and Debate: Special Section
}

\author{
Media Governance: \\ New ways to regulate the media
}

LEEN D'HAENENS

The following set of reflections emerged from a panel session that took place in June 2006 in Dresden as part of the International Communication Association, and out of a lively interaction among the six authors. We thought that the outcome of this reflection on the concept of media governance framed from different perspectives, from a philosophical concept to its diverse applications in the European Union, was important enough to dedicate a Commentary and Debate section to so that other people who were not in attendance could read it and share their visions with the editors.

There are good grounds to introduce self-and co-regulation in the media sector. For example the flexibility needed due to a rapidly changing (societal and technological) context, the constitutional reasons for a distance between politics and the media, as well as the fact that goals of pluralism and diversity are difficult to operationalize into effective laws. It also proves hard to enforce self-regulation. Therefore, it is important to find the right mix. 'Co-regulation' or 'regulated self-regulation' implies an important, albeit shared, role for the state. In addition, 'media governance' is a new concept in this respect. This also implies the involvement of civic and professional groups and mechanisms like public hearings in the process of media regulation.

Traditional media politics has leaned heavily on the state as central actor that has tried to achieve pluralism with relatively unclear goals. Those days seem to be gone for good as in recent decades a "transformation of statehood" (Latzer et al., 2003: 128) has taken place in the media and telecommunication sector which can be traced by trends such as a change from protectionism to promotion of competition, the separation of political and operative tasks (i. e. independent regulatory authorities), the shift from vertical (sector-specific) to horizontal regulation, the transition from national to supra- and international regulation, and the change from state to self-and co-regulation in which private and societal partners are becoming more actively involved in regulation.

In this Commentary and Debate section, six authors affiliated with the Universities of Hamburg and Zurich, and the Austrian Academy of Sciences distinguish between state regulation, co-regulation, and self-regulation and demonstrate that both in the literature and in the policy practice many alternative forms of regulation on the continuum between state and 
market based on collaborative arrangements between public and private partners have been elaborated on recently. The idea that market forces can simply replace government regulation has proven to be naïve. Instead of deregulation, we should speak of re-regulation. Also, the European Commission has been reflecting on new forms of regulation and governance. Its White Paper 'European Governance' (2001) emphasizes that co-regulation will be put to practice more and more. Although significant differences from country to country remain, for example between the Anglo-American legal model and continental Europe, the concept of the overarching state should be abandoned. The sovereign state has already made place for a corporate bargaining state, a partner embarking on partnerships with the industry.

In a theoretical background article, Patrick Donges demonstrates that media governance has gained in importance over the last few years, both as a scientific and theoretical approach for the analysis of media regulation and as a practical approach for new ways to regulate the media. He discusses the theoretical foundation of media governance, defines the term as a dynamic structure of rules among actors who are linked in different networks, connecting it to the new institutionalism concept in sociology.

Following up on this, Manuel Puppis considers media governance as a horizontal extension of government, covering not only statutory media regulation but also self- and co-regulation. These forms of regulation by private actors respect media freedom, while at the same time inflicting social responsibility on the media. The author discusses the role of the state in self-regulation, and argues that the government's involvement depends on the governance domain, the type of media platform, as well as national peculiarities.

Identifying media concentration as a fundamental problem for democracy, Werner Meier and Irène Perrin qualify media policy as increasingly influenced and controlled by corporate media. The authors' concept of media governance deals with the complex relationships of political, economic, and mass media power structures and is conceptualized as a multi-stakeholder approach which is supposed to 'tackle' complex conflicts of interest. Such a media governance approach surely is difficult to implement, but in the end it does not only help to legitimize media companies' editorial and corporate actions but it also assumes their obligations towards society.

Michael Latzer tackles the question of how to decide on the adequate mix of state and alternative regulation from a public-policy perspective. Based on the weighing of advantages and disadvantages of various modes of regulation and on international experiences with different regulatory modes, the author presents a rough guideline for regulatory and institutional choice. This model may assist decision-makers in assessing regulatory institutional arrangements for regulatory problems in the communication sector. 
Adopting a comparative approach, Matthias Kuenzler assesses the participation of the state in self-regulation as a potential key success factor (or not) for media governance. To this end, the author presents results from two empirical studies illustrating that the success of a state's participation depends on the domain of governance and that the involvement of the state is not the only key success factor.

Thorsten Held plays the comparative card even more, assessing the European Commission's stance as to the inclusion of co-regulatory systems when drafting the Audiovisual Media Services Directive (modifying and extending the European 'Television without Frontiers Directive'). The directive explicitly allows for co-regulation as a way to implement the directive's provisions including those for advertising and the protection of minors. According to article three, the member states shall encourage co-regulatory regimes in the fields coordinated by the directive. However, the term 'coregulation' includes a variety of different approaches for different countries and different sectors. The author briefly sketches some major findings of his investigations.

\section{Reference}

Latzer, M., Just, N., Saurwein, F., and Slominski, P. (2003). Regulation remixed: Institutional change through self and co-Regulation in the mediamatics sector. Communications and Strategies 50 ( $2^{\text {nd }}$ quarter 2003), 127-157.

\section{The New Institutionalism as a theoretical foundation of media governance}

PATRICK DONGES

\section{Governance as a structure of rules}

Governance is a new approach in the discussion on media regulation and has gained in importance over the last few years. As a more theoretical approach, we find the concept of governance in several scientific disciplines like political science, law, economics, or sociology, where it is applied to several theoretical levels and for a plurality of research questions. As a more practical approach, the concept is discussed in several countries with different traditions in media regulation. Nevertheless, the question whether governance is just a stylish buzzword or a plausible and useful approach is still in discussion (e.g., Benz, 2004).

In a broad sense, the concept of governance refers to the relations between actors and the ways in which these actors reduce specific risks and uncertainties within their interaction "in order to make cooperation 
possible or easier" (Van Kersbergen and Van Waarden, 2004: 152). For the German sociologists Schimank and Lange (2004: 19), governance generally means a pattern to cope with interdependence between actors. The notion of 'pattern' indicates that governance means both the processes of coping with interdependency and the structures wherein these processes take place. Lange and Schimank (2004: 19-22) mention three basic forms of governance structures: Reciprocal observation, reciprocal influence, and bargaining.

In a narrower sense, the several notions of governance differ in their understanding, depending on what problems of interdependence they focus on. In economics, the basic problem of governance is to control and to assert rules that have been accepted in a contract by opportunistic actors (Richter and Furubotn, 1997). In political science, governance refers to the enforcement of collectively binding rules in times where the state is no longer a homogenous and unitary actor but a network of actors which are only partially coupled in a hierarchical way (Mayntz, 2005: 15). This is especially the case when processes and structures of governance cross borders; for instance the borders between organizations and their environment, between state and society, or the borders between nations (Benz, 2004: 25). In these cases, policy-making is no longer a process of setting rules but a complex process of institutionalized negotiations within political (not necessarily governmental actors) and other actors in multilevel systems (e. g., Benz, 2005).

In short, governance refers to the dynamic structure of rules between actors that are linked in different networks and permanently forced to negotiate, without a center that has the power to command and control. As an analytic approach, governance focuses on the impact of these structures of rules on the actors and their behavior. In an effort to take the discussion one step further and to answer the 'buzzword or useful approach?' question, the concept of governance has to be connected to social science theories which highlight such dynamics between structures and actors. In my opinion, a fruitful theoretical foundation of the governance approach can be found in institutional theories, especially the new institutionalism in sociology.

\section{Insights from the new institutionalism in sociology}

Within the new institutionalism, institutions can be defined as "symbolic and behavioral systems containing representational, constitutive and normative rules together with regulatory mechanisms that define a common meaning system and give rise to distinctive actors and action routines" (Scott, 1994: 68). As Barley and Tolbert (1997: 96) pointed out, institutions are "shared rules and typifications that identify categories of 
social actors and their appropriate activities or relationships." They are socially constructed and routine-reproduced, because actors take them for granted and internalize them (Jepperson, 1991: 149).

According to the new institutionalism, institutions are more than just the rules of the game. Social actors cannot use institutional rules just the way they want. Institutional rules are constraints to actors as they limit their range of behavior. However, they also create actors and enable them to act. Actors develop their preferences within an institutional environment, defined as the "rules and requirements to which [individuals and] organizations must conform if they are to receive support and legitimacy" (Scott and Meyer, 1991: 123).

What can we learn from the new institutionalism for the debate on media governance? Three points should be emphasized in this respect:

(1) Actors such as media organizations (institutionalized as private or public companies) or regulatory authorities etc. cannot be considered decoupled from the institutional setting they emerged from. Moreover, institutional rules define how organizations observe and evaluate their environment. Organizations bear their institutional history inside and cannot shake it off. They are path dependent in the sense that it is hard to change their structures.

(2) Institutional rules are the basis of media regulation, and all forms of regulation are always rooted in institutional arrangements. That is the reason why we can distinguish different models of media and politics (e. g., Hallin and Mancini, 2004) or different 'ideas' or regulatory cultures even within Europe (e.g., Cuilenburg and McQuail, 2003; see e. g., Napoli, 1999).

(3) Institutional rules are always the products of decisions made by media, political, or economic actors. However, the emergence of such rules is not always intended. "While institutions are certainly the result of human activity, they are not necessarily the products of conscious design" (DiMaggio and Powell, 1991: 8). Particularly, a time lag has to be considered: "The critical agenda for institutional analysis should be to show how choices made at one point in time create institutions that generate recognizable patterns of constraints and opportunities at a later point" (Powell, 1991: 188). Media actors cannot 'make' institutions. However, one has to consider that institutions emerge, and become accepted only with the help of powerful actors. Processes of institutionalization are dependent on actors who support and try to influence these, but once institutionalized, rules are taken-for-granted, and actors are unlikely to recognize alternatives. 


\section{Institutionalized rules of media governance and media regulation}

The following are three connections between media governance as a structure of rules, the new institutionalism, and media regulation:

(1) Institutionalized rules of media governance are the basis of media regulation. All forms of regulation build on existing governance structures and institutionalized rules (path dependency). Such rules may concern the organizational form of media organizations (private, public service), the connection between media organizations and the state or political actors, or the perception about which regulatory decisions are legitimate and which are not. Even a cursory look at European media systems shows that these normative and cultural rules differ a lot while the regulatory rules (notion of media freedom) remain nearly the same.

(2) Institutionalized rules of media governance are the outcome of media regulation. Regulatory decisions may change governance structures, even though the change is not always intended. Governance structures may be complementary or even contradictory, as can be illustrated through the diverging views on the role of public service broadcasting on a national and the European policy level (see e. g., Cuilenburg and McQuail, 2003; see e.g., Harrison and Woods, 2001).

(3) Institutionalized rules of media governance may be used (in a restricted way) as an instrument of media regulation. Mainly in AngloSaxon countries, broadcasting policy focuses on the indirect regulation of the process of content production, but not on the content itself (as in France or Germany). Political actors have the opportunity to take part in the institutionalization of governance structures by linking several networks of actors, modifying the rules of governance structures, obliging the actors involved to negotiate rules, build new kinds of bonds among themselves, and integrate in established networks etc. One example is the obligation for public consultations whenever new broadcasting acts are being prepared. This is a well- known practice in Anglo-Saxon countries like Canada (e. g., Raboy, 1994). The regulatory decision to bring the society into processes of governance will lead to the establishment of new actors and will change the existing rules of the game. Structures of media governance may not be changed dramatically or replaced by a new order 'of a piece', but will only be modified slowly, bit by bit.

\section{Discussion}

In short, we consider media governance to have two meanings. First, it is both a scientific and theoretical approach to analyze different forms 
of media regulation. The governance approach considers media regulation as a process within a network of actors in which the government may be, but not necessarily has to be involved. As a theoretical approach, media governance indicates the relevance of institutional rules and would gain from being connected to new institutional approaches in social sciences. Secondly, media governance may be seen as an instrument of media regulation. Governmental actors or regulatory authorities set rules or may commit other actors to negotiate rules.

With this connection to institutional thinking, media governance can be a possible and fruitful theoretical bridge between several scientific disciplines, and theoretical paradigms. With its theoretical foundation in rules, institutions, and relationships between actors, the approach connects with several disciplines like sociology, political science, economics, or law. As a more practical approach in media regulation, media governance bridges the experiences made within different regulatory cultures, particularly the Anglo-Saxon tradition and the Central-European.

\section{References}

Barley, S. R. and Tolbert, P. S. (1997). Institutionalization and structuration: Studying the links between action and institution. Organization Studies, 18(1), 93-117.

Benz, A. (2004). Einleitung: Governance - Modebegriff oder nützliches sozialwissenschaftliches Konzept? In A. Benz (Ed.), Governance - Regieren in komplexen Regelsystemen. Eine Einführung (pp. 11-28). Wiesbaden: Verlag für Sozialwissenschaften.

Benz, A. (2005). Governance in Mehrebenensystemen. In G. F. Schuppert (Ed.), Governance-Forschung. Vergewisserung über Stand und Entwicklungslinien (pp. 95120). Baden-Baden: Nomos.

Cuilenburg, J. van and McQuail, D. (2003). Media policy paradigm shifts. Towards a new communications policy paradigm. European Journal of Communication, 18(2), $181-207$.

DiMaggio, P. J. and Powell, W. W. (1991). Introduction. In P. J. DiMaggio and W. W. Powell (Eds.), The new institutionalism in organizational analysis (pp. 1-38). Chicago, London: University of Chicago Press.

Hallin, D. C. and Mancini, P. (2004). Comparing media systems. Three models of media and politics. Cambridge: Cambridge University Press.

Harrison, J. and Woods, L. M. (2001). Defining European public service broadcasting. European Journal of Communication, 16(4), 477-504.

Jepperson, R. J. (1991). Institutions, institutional effects, and institutionalism. In P. J. DiMaggio and W. W. Powell (Eds.), The new institutionalism in organizational analysis (pp. 143-163). Chicago, London: University of Chicago Press.

Lange, S. and Schimank, U. (2004). Governance und gesellschaftliche Integration. In S. Lange and U. Schimank (Eds.), Governance und gesellschaftliche Integration (pp. 9-44). Wiesbaden: VS Verlag für Sozialwissenschaften.

Mayntz, R. (2005). Governance Theory als fortentwickelte Steuerungstheorie? In G. F. Schuppert (Ed.), Governance-Forschung. Vergewisserung über Stand und Entwicklungslinien (pp. 11-20). Baden-Baden: Nomos.

Napoli, P. M. (1999). The marketplace of ideas metaphor in communications regulation. Journal of Communication, 49(4), 151-169. 
Powell, W. W. (1991). Expanding the scope of institutional Analysis. In P. J. DiMaggio and W. W. Powell (Eds.), The new institutionalism in organizational analysis (pp. 183-203). Chicago, London: University of Chicago Press.

Raboy, M. (1994). The role of the public in broadcasting policy-making and regulation: Lessons for Europe from Canada. European Journal of Communication, 9(1), $5-23$.

Richter, R. and Furubotn, E. G. (1997). Institutions and economic theory: The contribution of the new institutional economics. Ann Arbor: University of Michigan Press.

Scott, W. R. (1994). Institutions and organizations. Toward a theoretical synthesis. In W. R. Scott and J. W. Meyer (Eds.), Institutional environments and organizations. Structural complexity and individualism (pp. 55-80). Thousand Oaks, London, New Delhi: Sage.

Scott, W. R., and Meyer, J. W. (1991). The organization of societal sectors: Propositions and early evidence. In P. J. DiMaggio and W. W. Powell (Eds.), The new institutionalism in organizational analysis (pp. 108-140). Chicago, London: University of Chicago Press.

Van Kersbergen, K. and Van Waarden, F. (2004). 'Governance' as a bridge between disciplines: Cross-disciplinary inspiration regarding shifts in governance and problems of governability, accountability and legitimacy. European Journal of Political Research, 43(2), 143-171.

\section{Media Governance as a horizontal extension of Media Regulation: The importance of Self- and Co-Regulation}

MANUEL PUPPIS

\section{From media regulation to media governance}

A media governance perspective not only underlines the relevance of non-statutory regulation but also questions the role of the state. This paper first discusses governance as a horizontal extension of government covering statutory regulation as well as self- and co-regulation. Second, potentials and risks of these forms of governance are dealt with. Third, different domains of media governance will be distinguished before looking into the varying role of private actors and the state in them. Due to the fact that media are not seen as just another commodity but as playing a crucial political, social, and cultural role for society, media regulation is predominantly a matter of the nation state. However, what exactly is regulation?

Broadly, statutory regulation means that the state formulates and enforces rules and sanctions non-compliance with these rules. Or, as Baldwin and Cave (1999: 2) put it, statutory regulation refers to a "deliberate state influence" and "covers all state actions designed to influence industrial or social behavior" (i. e. command-based regimes, economic incentives, and the supply of information). Statutory media regulation 
then means the regulation of the media. Mass media, for their part, stand for the "organized means of communicating" whereas the "process of mass communication and the actual media that make it possible" can be distinguished (McQuail, 2005: 4, 24). Accordingly, statutory media regulation can be defined as the formulation and enforcement of rules as well as the sanctioning of non-compliance regarding media organizations and the processes of mass communication they are organizing. Statutory regulation is partly implemented by so-called regulatory agencies which operate on the basis of a legislative mandate (Majone, 1996a: 9).

However, there are other possibilities of regulation. These days we observe a shift from statutory media regulation (or government) to media governance. On the one hand, the influence of European and global regulation is increasing. On the other hand, forms of regulation where private actors are involved (self- and co-regulation) are becoming more important (Puppis and Künzler, 2007). The concept of media governance encompasses both developments and stands for a horizontal as well as a vertical extension of government (see Figure 1). As Mayntz (2004: 66) has pointed out, governance can be understood as the regulatory structure as a whole, combining public and private, hierarchical and network forms of action coordination.

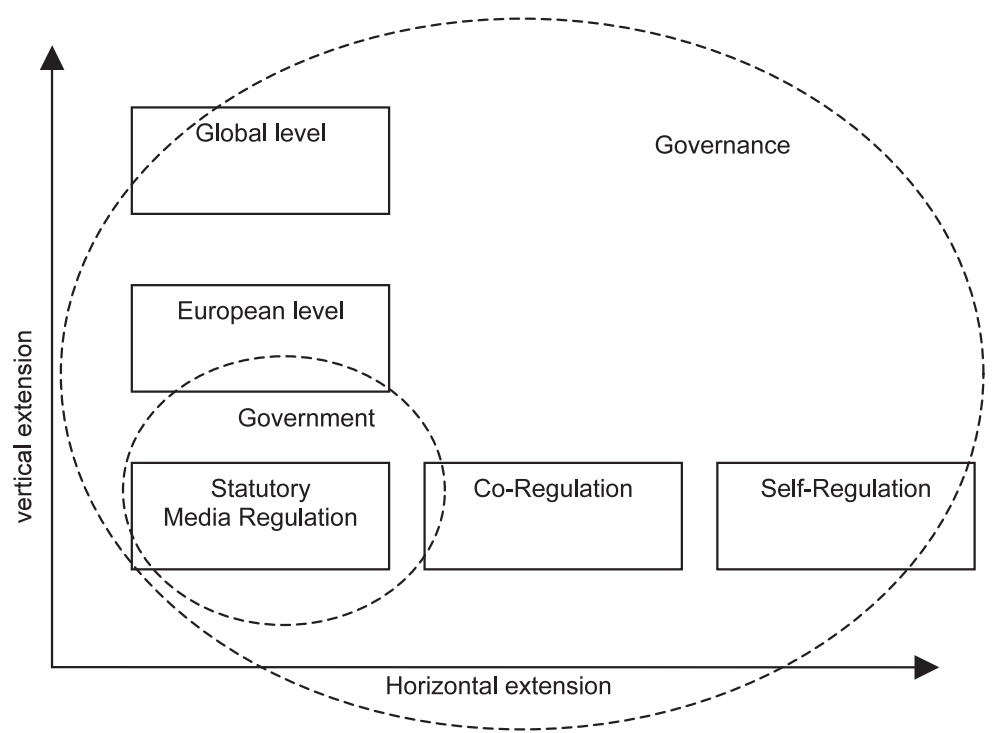

Figure 1. Media governance as horizontal and vertical extension of government.

Source: Puppis (2007: 62) 
Regarding the horizontal extension of government, the term 'media governance' covers statutory media regulation as well as self- and coregulation in the media. While the state is not involved in self-regulatory organizations (apart from supposable pressure on the industry), co-regulation is taking place within a framework provided by the state and refers to a mix of statutory regulation and self-regulation (Jarren et al., 2002; Latzer, 2002; Schulz and Held, 2004):

- Self-regulation describes forms of regulation where private actors formulate and enforce rules and sanction non-compliance directed towards their own industry.

- Co-Regulation refers to the formulation and enforcement of rules and the sanctioning of non-compliance by private actors who are mandated to do so and who work together with the state (mostly regulatory agencies). This means that self-regulation is taking place within a framework provided by the state. The term 'regulated self-regulation', which is often used in the German-language literature as a synonym for co-regulation, seems quiet fitting to describe this arrangement.

\section{Potentials and risks of non-statutory regulation}

Politicians and media companies alike often argue that statutory media regulation alone is not sufficient, and that 'new' forms of regulation are needed. The participation of private actors in broadcasting regulation is seen as both a possibility of re-regulation and a solution for the dilemma how to reconcile media freedom and media regulation.

First, statutory media regulation encounters several difficulties causing a need for re-regulation. Not only did traditional regulation by the state come under pressure due to ideological changes and economic interests, its shortcomings in consequence of technical changes and commercialization became apparent as well (Dyson and Humphreys, 1989). The introduction of private broadcasting in Western European countries ('dualization'), the globalization of the media industry as well as the digitization and convergence of media technology cast doubt that the state alone can effectively regulate the media. Additionally, statutory media regulation has problems to cope in the new media field. It is believed that the participation of private actors through self- and coregulation will avoid these problems. A number of advantages are often associated with self-regulatory organizations: They are said to be more flexible, faster, more cost-effective and to have more expertise than regulatory agencies (Baldwin and Cave, 1999; Majone, 1996a: 23; Ogus, 2000). 
However, statutory media regulation raises a second problem which is an even more important rationale for self- and co-regulation. Media regulation is always between a rock and a hard place. While there are legitimate societal, economic, and technical justifications for media regulation, in democratic societies the media should be devoid of governmental influence. Accordingly, media freedom restricts the scope of media regulation. Non-statutory media regulation may be a solution for this dilemma of media regulation: media freedom is respected because the media regulate themselves.

Despite the potential of self- and co-regulation there are also risks to keep in mind (Baldwin/Cave, 1999; Majone, 1996a; Ogus, 2000). First, self-regulation is mostly introduced to keep the state off from regulation and not because the industry has secret desires for more rules. Second, self-regulation may conduce to the realization of private interests rather than the public interest. "With self-regulation, regulatory capture is there from the outset" (Kay quoted in Ogus, 1994: 108). Third, self-regulation lacks democratic legitimacy. Most importantly, however, it is questionable if self-regulation is really compulsory enough. There exists no guarantee that self-imposed rules will indeed be enforced and that non-compliance will be sanctioned. These problems raise the question of whether the state should be involved in self-regulation. For instance, Majone (1996a: 26) argues that "the presence of a forceful public regulator is needed in order to "guard the guardians"'. This brings us back to media governance. A governance perspective on regulation not only highlights the importance of non-statutory regulation but also the choice between different forms of regulation, "regulatory choice", as Schuppert (2005: $395)$ termed it, and the role of the state in self-regulation.

\section{Domains of media governance}

Given the aspects above, we ask ourselves: Which form of regulation is the right choice? And should the state be involved in self-regulation? It is impossible to provide answers that are valid for the media sector as a whole. Rather we have to acknowledge that the role of private actors and the state varies. Therefore, it is suggested to distinguish between different domains of media governance: The regulation of organizations, of ownership, of funding, of distribution, of processes and of content.

- Organizations: In many countries public service broadcasters were institutionalized. Furthermore, private broadcasters require a license from the state.

- Ownership: By means of ownership restrictions it is the aim to curb media concentration and cross-ownership in order to preserve diver- 
sity. Regulation of media ownership and concentration can go beyond the general competition law applicable to all sectors of economy. For instance, it is possible to restrict the permitted viewer market share of any single company or to limit the number of licenses a company may obtain.

- Funding: Public service broadcasters are at least to some extent funded by public money. Subsidies for the media industry (i.e. for the press and for audio-visual production) are common as well. Additionally, advertising restrictions exist in broadcasting.

- Distribution: Digitization poses a challenge for the electronic communications infrastructure and creates new bottlenecks. The companies who own the infrastructure required to reach their audience can act as gatekeepers. They have the power to decide who gets access to their network and their facilities (e.g., Conditional Access System, Application Programming Interface, Electronic Program Guide).

- Processes: The process of creating editorial content, for instance journalistic work processes, is another domain of media governance.

- Content: While content requirements refer to broad principles like objectivity, impartiality, or diversity as well as quotas for national and European content, content restrictions impose limits on the dissemination of certain types of content (Bernier, 2004: 216f.).

Which form of regulation is the right choice? It is suggested that self- and co-regulation do not occur in all these domains of media governance. In some of them, statutory media regulation prevails (e. g., in ownership regulation there are no private actors involved for good reasons). Nonstatutory forms of regulation are especially relevant in the regulation of organizations, of distribution, of processes, and of content. In the regulation of organizations, the board of public service broadcasters is mostly responsible for the self-regulation of these organizations (e.g., setting internal guidelines). In the regulation of distribution, self-regulatory organizations are often concerned with technical standardization or the management of internet core resources. In the regulation of processes, no statutory regulation exists. Horizontal extension of government means that a self-regulatory organization is enforcing rules for journalistic work processes and the presentation of information. In many countries, press councils are not only responsible for printed media but also for broadcasting and the Internet. In the regulation of content, horizontal extension of government means that a self-regulatory organization is concerned with content restrictions. The aim is to prevent or to restrict the dissemination of content that is perceived to be inappropriate for minors (e. g., representation of sex and violence). Examples are the Australian system of content regulation or the German 'Freiwillige Selbstkontrolle 
Fernsehen' (voluntary self-regulation of television). The latter inspects fictional programming before dissemination and decides on transmission time and necessary cuts.

Should the state be involved in self-regulation? Based on results of comparative research projects (Jarren et al., 2002; Puppis et al., 2004; see Matthias Künzler in this section for more details) it is assumed that the role of the state in media governance varies across these domains. Instead of no state at all, co-regulation is often preferred to self-regulation. By bringing the state back in, the aim is to tap the potentials of nonstatutory regulation while at the same time preventing its risks. The question regarding the role of the state in self-regulation in different domains of media governance is highly relevant as it is connected to the bindingness and the legitimacy of governance. First, questions surrounding the effectiveness of self-regulation ('regulatory impact assessment') come to the fore. Second, it can be doubted that self-regulation results in democratically legitimated regulation in the public interest. With coregulation, however, an obligation to be accountable and transparent can foster procedural legitimacy (Majone, 1996b: $291 \mathrm{f}$.). In the end, there is no easy answer. Whether media governance by private actors should involve government or not, depends on the domain of governance, the type of media in question as well as national structures and traditions.

\section{References}

Baldwin, R. and Cave, M. (1999). Understanding Regulation. Theory, Strategy, and Practice. Oxford/New York: Oxford University Press.

Bernier, I. (2004). Content regulation in the audio-visual sector and the WTO. In D. Geradin and D. Luff (Eds.), The WTO and global convergence in telecommunications and audio-visual services (pp. 215-242). Cambridge: Cambridge University Press.

Dyson, K. and Humphreys, P. (1989). Deregulating broadcasting. The West European experience. European Journal of Political Research, 17(2), 137-154.

Jarren, O., Weber, R. H., Donges, P., Dörr, B., Künzler, M., and Puppis, M. (2002). Rundfunkregulierung. Leitbilder, Modelle und Erfahrungen im internationalen Vergleich. Eine sozial- und rechtswissenschaftliche Analyse. Zürich: Seismo.

Latzer, M., Just, N., Saurwein, F., and Slominski, P. (2002). Selbst- und Ko-Regulierung im Mediamatiksektor. Alternative Regulierungsformen zwischen Staat und Markt. Wiesbaden: Westdeutscher Verlag.

Majone, G. (1996a). Regulation and its modes. In G. Majone (Ed.), Regulating Europe (pp. 9-27). London/New York: Routledge.

Majone, G. (1996b). Regulatory legitimacy. In G. Majone (Ed.), Regulating Europe (pp. 284-301). London/New York: Routledge.

Mayntz, R. (2004). Governance im modernen Staat. In A. Benz (Ed.), Governance Regieren in komplexen Regelsystemen. Eine Einführung (pp. 65-76). Wiesbaden: VS Verlag. 
McQuail, D. (2005). McQuail's mass communication theory (5 ${ }^{\text {th }}$ ed.). London/Thousand Oaks/New Delhi: Sage.

Ogus, A. (2000). Self-regulation. In B. Bouckaert and G. D. Geest (Eds.), Encyclopedia of law and economics, volume $V$. The economics of crime and litigation. (pp. 587602). Cheltenham: Edward Elgar.

Ogus, A. I. (1994). Regulation. legal form and economic theory. Oxford/New York: Oxford University Press.

Puppis, M. (2007). Einführung in die Medienpolitik. Konstanz: UVK.

Puppis, M. and Künzler, M. (2007). Governance als horizontale Ausweitung von Government: Selbst- und Co-Regulierung im Medienbereich. In P. Donges (Ed.), Von der Medienpolitik zur Media Governance? Köln: Halem.

Puppis, M., Künzler, M., Schade, E., Donges, P., Dörr, B., Ledergerber, A., and Vogel, M. (2004). Selbstregulierung und Selbstorganisation. Zürich: IPMZ.

Schulz, W. and Held, T. (2004). Regulated self-regulation as a form of modern government. An analysis of case studies from media and telecommunications law. Eastleigh: John Libbey.

Schuppert, G. F. (2005). Governance im Spiegel der Wissenschaftsdisziplinen. In G. F. Schuppert (Ed.), Governance-Forschung. Vergewisserung über Stand und Entwicklungslinien (pp. 371-469). Baden-Baden: Nomos.

\section{Media Concentration and Media Governance}

WERNER A. MEIER and IRENE PERRIN

\section{Concentration of political and economic power}

Media concentration is a concentration of economic and societal power. It poses a fundamental problem for democracies. Since market-leading media companies have no incentive to prevent concentration, as concentration strengthens a company's competitive position and prevents potential competitors from entering the market, a multitude of small independent media companies have merged into a small number of big media companies.

National oligopolies and regional monopolies are becoming common, although both types of market structure contradict the existing economic order. However, they prevail because dominant players defend their privileges. Media tycoon Rupert Murdoch points out this contradiction by objecting to competitors" monopolies, while defending his own: "Monopolies are terrible things ... until you have one" (Financial Times, November 13, 2004). Media concentration provides media companies with exclusive access to the public, which means that media companies can count on preferential treatment in politics (cf. Barnett, 2004). Thus, media policy is increasingly controlled by corporate media which are able to influence the regulatory framework and state measures in the media sector (cf. Schäfer, 1999). As public discourse mostly takes place in the media, the potential of negative consequences for democracy such 
as less democratic pluralism, less political and cultural diversity, and increasing power for some privileged social actors, is generally played down or ignored. The general failure to fight media concentration effectively is not surprising, considering the low visibility of the media concentration debate. A majority of European countries have passed competition legislation and media concentration laws. However, these laws have proven to be unable to prevent ownership concentration in media. In media policy practice, the focus of regulation is on ensuring economic competition. Legislation rather aims at making local media industries more competitive on international markets than at securing media quality and diversity. Obviously, economic interests prevail over societal or democratic interests.

\section{Media governance on the way to democratic governance?}

The proposed concept of media governance deals with the complex relationships of political, economic, and mass media power structures. It analyzes and evaluates existing power structures and their effects on all stakeholders involved. Media governance should be able to grasp complex power structures within media organizations and between media organizations and other institutions on both a theoretical and a practical level (cf. Picard, 2005). The governance of the media "(...) covers all means by which the mass media are limited, directed, encouraged, managed, or called into account, ranging from the most binding law to the most resistible of pressures and self-chosen disciplines" (McQuail, 2003: 91).

A certain degree of tension between constitutional media freedom and media responsibility for democracy is inherent in all forms of media governance. Denis McQuail has coined an apt expression for this tension. He called it "controlling free media" (McQuail, 2003: 91). The government is unable to secure quality and performance of media, but it can formulate laws and regulations which safeguard these objectives.

The creation of multimedia companies and the investment of private equity in media result in an increasing commercialization of content. They make it more difficult to balance corporate, professional, journalistic, and societal interests with institutional and individual shareholders' interests. Ultimately, media governance is supposed to mediate rising conflicts of interest by creating a platform which empowers previously neglected stakeholders, mainly civil society, and at the same time encourage the state and media organizations to assume their obligations to society. Thus, media governance paves the way for democratization of media and society by asking whose interests dominate media companies, 
to whose end they operate, and by integrating the 'neglected' interests into the media organization.

Thus, the concept of media governance is conceptualized as a multistakeholder approach which is supposed to 'tackle' complex conflicts of interest in media policy. The stakeholder approach takes into account different stakeholders' interests within corporate actions (cf. Freeman, 1984; Post, Preston et al., 2002). Companies tend to accommodate stakeholders which are vital to their success, such as shareholders, employees, suppliers, and customers, but neglect stakeholders with little or no power but which nonetheless have justified claims and expectations (cf. Mitchell, Agle et al., 1997).

As media governance is based on a systematic, comprehensive, and institutionalized multi-stakeholder approach it is able to integrate (neglected) stakeholder interests on various levels. Civil society, which so far only appeared in the role of the audience, is participating in media governance processes alongside established stakeholders such as media organizations, economic interests, and state authorities. Companies are no longer acting only in corporate interest but also in society's. And corporate performance is judged from various perspectives (cf. Post, Preston et al., 2002: 17).

Media companies are not only accountable to employees, advertising clients, consumers, and investors but also to other stakeholders such as the public, the community where they are based, and to political and cultural institutions which rely on media performance. To accommodate these contradictions and conflicts in theory and in practice, two types (public and corporate governance) containing five forms of media governance are suggested.

Firstly, these five forms of media governance are supposed to offer a sufficiently sophisticated tool for analysis to look into the conflicts associated with media concentration. Secondly, a media policy concept (soft governance) is to be developed to complement state measures. Thirdly, a discursive and interactive platform is to be created, where power assertion and claims of power can be judged on their legitimacy. These five forms can be divided into two types, namely public governance of media, and media corporate governance.

Type A: Public governance of media includes all measures which ensure that media serve the public interest and civil society. State media policy is at the centre of public governance. State governance (1) of media focuses on the general framework for media, brought in by the state and society, in form of media, competition and anti-trust law.

Type B: Media corporate governance concepts are known under the terms 'good corporate governance', 'good corporate citizenship', or 'corporate 
social responsibility'. External corporate media governance (2) includes corporate rules concerning conduct of the management in relation to newsrooms and to civil society. Ownership governance (3) includes mission statements of media organizations aiming at a socially responsible and sustainable media order. Private media however are usually not answerable to the public, only to shareholders and owners. Internal corporate media governance (4) focuses on power structures within organizations, for example relation of power between management, board and investors or shareholders, and on management's influence on the news production process. In the literature, the latter type is called 'news governance' within media organizations (cf. Arrese, 2005). The fifth form of media governance records the contribution and efforts of media to promote democracy. Governance by media coverage (5) focuses on the contribution of media content to a democratic society. The idea is to measure media's functioning as a public watchdog of the state and the economy.

\section{Media governance: Application to forms and consequences of concentration}

The first practical test of the approach suggested consists of an attempt to formulate a concept of governance adequate to the forms and consequences of media concentration. In the following, the concept is put up for discussion (see table 1), and some of the proposed governance mechanisms are presented.

Concentration and the strengthening of a dominant position increase the probability of abuse. Therefore, accountability and transparency guidelines are desirable. Tougher rules for ownership transparency (shareholders, interests of management, corporate integration) are as important as quality assurance measures (in-house journalism criticisms). As is common in other sectors, these efforts and measures are to be published in an annual Corporate Governance Report.

OECD has published transparency guidelines which can be applied to media companies (cf. OECD, 2004; 2005). In addition, leading media companies are supposed to ensure the transparency of the separation between newsroom and management. A noteworthy example is the Washington Post: "The newspaper's duty is to its readers and to the public at large, and not to the private interests of the owner" (Final Report on the Canadian News Media 2006: 132). Media companies are obliged to make sure their coverage of media includes causes, forms, and consequences of media concentration and political efforts to prevent concentration. It has to be said, though, that media journalism soon reaches a limit (cf. Fengler/Russ-Mohl, 2006). 
340 Media Concentration and Media Governance

\begin{tabular}{|c|c|c|c|c|c|}
\hline 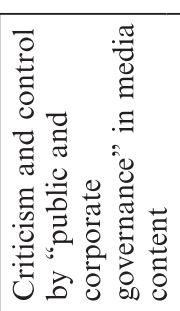 & 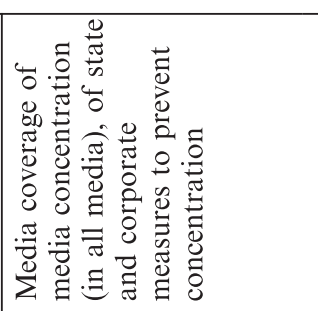 & 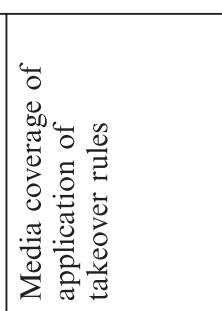 & 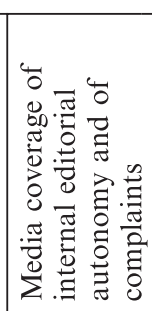 & 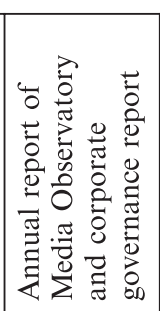 & 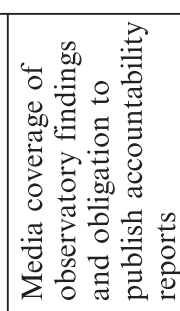 \\
\hline 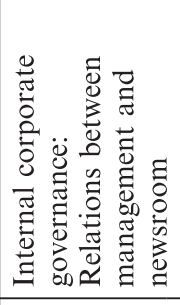 & 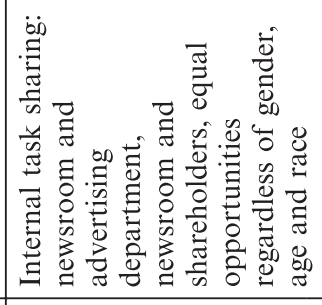 & 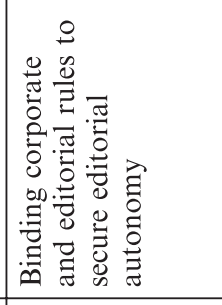 & 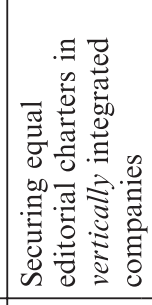 & 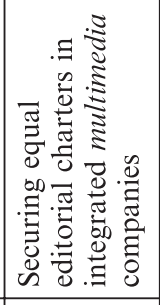 & 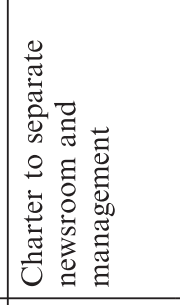 \\
\hline 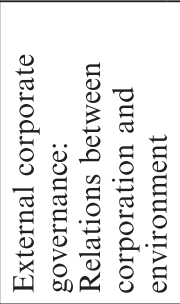 & 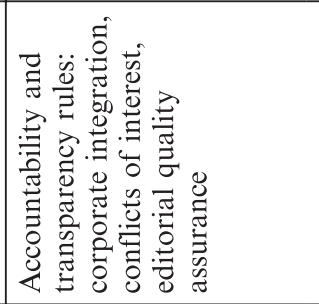 & 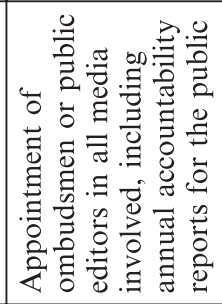 & & 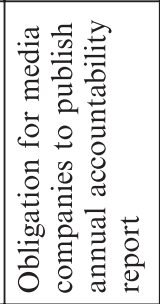 & 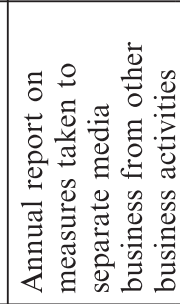 \\
\hline 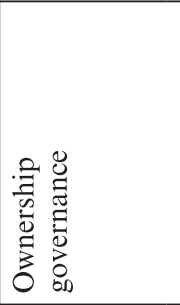 & 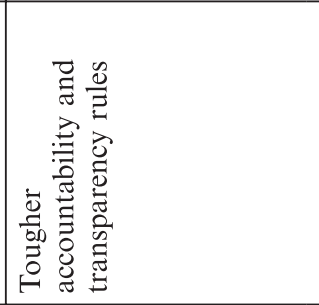 & 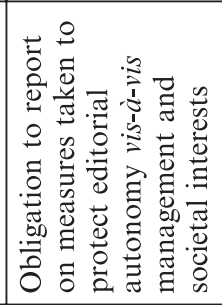 & 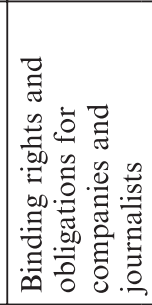 & 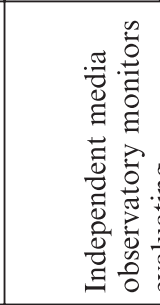 & 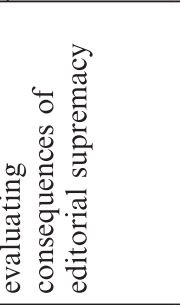 \\
\hline 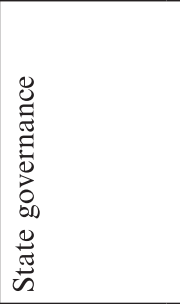 & 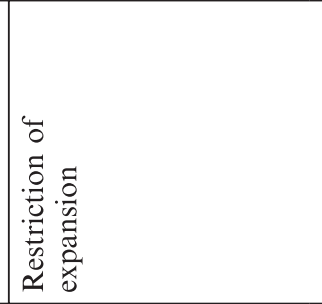 & 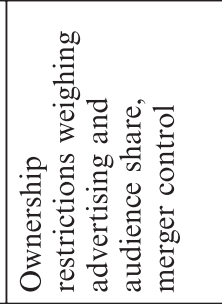 & 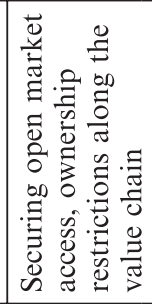 & 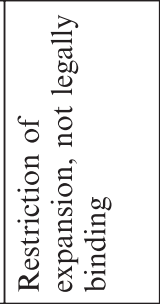 & 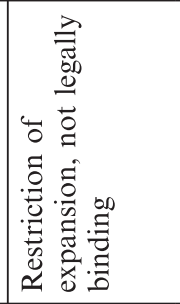 \\
\hline 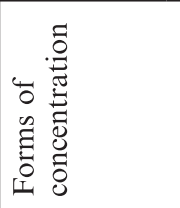 & 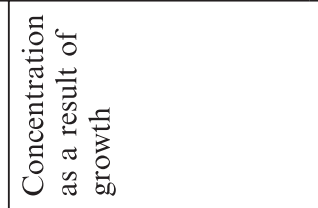 & 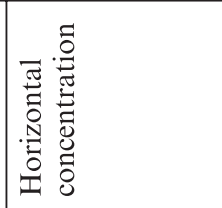 & 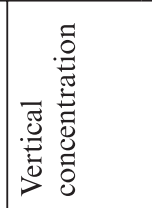 & 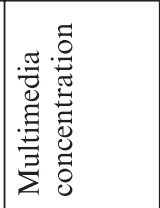 & 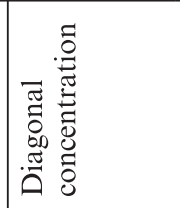 \\
\hline
\end{tabular}


In addition, an independent media observatory could be discussed, as well as the institution of Public Editors or ombudsmen and a publication of corporate and newsroom accountability reports alongside internal guidelines. These measures would encourage investigative reporting.

The media observatory has been described elsewhere in detail (cf. Jarren et al., 2002). The observatory as a competence centre is supposed to provide reliable and up-to-date data on media concentration for use in public discourse and to point out emerging problems. A media observatory aims at recording forms of media concentration which are so far not on the radar of media policy.

Corporate ombudsmen are appointed and instructed by the media themselves. They serve as contact points for societal stakeholders who are not adequately represented in certain media. In this way, ombudsmen offer a platform of mediation between interests of the public and interests of the media (management and newsroom). The complaints lodged against a company are collected by the ombudsman and published in an appropriate form in regular intervals. The Public Editor has to be provided with his or her own editorial space or a platform to publish corrections of, and further thoughts on contributions which were objected to.

Media companies have started to publish corporate governance statements because of rising pressure from shareholders and politicians. This applies to private media companies as well as Public Service organizations. Corporate governance, however, fails to allow for media-specific characteristics. For example, media concentration rules should be added. A governance statement should include reports about the status quo and progress in introducing editorial guidelines, newsroom charters, and the separation of newsroom and management. It should also describe a company's efforts to secure editorial autonomy within a larger media conglomerate. Editorial representatives and management would have to take a stand.

The governance report could be presented in a public hearing, which representatives of different stakeholders such as civil society, politics, and media companies would attend. These events would serve to articulate and negotiate expectations in structured dialogues, chaired each time by a different stakeholder.

Editorial charters and corporate guidelines are fundamental to many media organizations' business. They focus on quality assurance, editorial autonomy, and diversity. To prevent negative consequences of media concentration, media are obliged to secure editorial autonomy from advertising clients, the advertising department, and the management. A charter of separation deals with the relationship between shareholders, management board, and the editorial department (such as the right of shareholders and editorial board to interfere with editorial and staff deci- 
sions, etc.). Such a charter is particularly relevant in diagonally integrated companies. The charter of separation also includes rules for the budgeting process negotiated among different departments.

\section{Conclusion}

Traditional media and concentration politics can be seen as the sum of all measures and instruments within the framework of legislation which regulate concentration in the media sector. They have so far been ineffective when applied to big media companies. Efforts have not proven to be successful neither on the national nor on the international level, with some exceptions such as the failed takeover of Pro Sieben Sat.1 by Axel Springer in spring 2006. If the economic imperative continues to assert itself over editorial and diversity objectives, additional instruments like those recommended in our Media Governance approach should be considered and be evaluated.

In order to take different stakeholders' interests into account and to implement a multi-stakeholder approach, it is crucial to create new institutions, processes, and systems which include both societal and economic interests and report on the performance in both areas. New institutions are necessary because traditional reporting mainly focuses on shareholders' interests. However, a media governance approach which takes into account a multi-stakeholder perspective is difficult to implement, but in the end it helps to legitimize media companies' editorial and corporate actions in society. Increasing media power and influence of media demands balancing counterchecks: "There seems to be a growing consensus that increasing 'power' or, better, 'influence' of the media has to be counterbalanced by greater media transparency and accountability" (Bardoel and d'Haenens, 2004: 10).

\section{References}

Arrese, A (2005). Corporate governance and news governance in economic and financial media. In R. Picard (Ed.), Corporate Governance of Media Companies. (pp. 77-125). Jönköping.

Bardoel, J. and d'Haenens, L. (2004). Media responsibility and accountability: New conceptualizations and practices, Communications, 29(1), 5-25.

Barnett, S. (2004). Media ownership policies: Pressures for change and implications. Pacific Journalism Review, 10(2), 8-19

Fengler, S. and Russ-Mohl, S. (2006). The three paradoxes of media journalism. In S. Egli von Matt, C. Elia, and S. Russ-Mohl (Eds.), Journalism in the Attention Cycle: Problems, Perspectives, Visions (pp. 15-21). Milan.

Freeman, R. E. (1984). Strategic management: A stakeholder approach. Boston, Pitman.

Jarren, O. a.o. (2002). Medienrat und l'observatoire suisse des médias. Zürich (http:// www.mediapolicy.unizh.ch/transfer/observatoire.php) 
McQuail, D. (2003). Media accountability and freedom of publication. Oxford, New York.

Mitchell, R. K., Agle, B. R. et al. (1997). Toward a theory of stakeholder identification and salience: Defining the principle of who and what really counts. Academy of Management Review, 22(4), 853-886.

OECD (2004). OECD principles of corporate governance. Paris.

OECD (2005). Guidelines on the corporate governance of state-owned enterprises. Paris

Picard, R. (2005). Corporate governance: Issues and challenges. In R. Picard (Ed.), Corporate Governance of Media Companies. Jönköping, 1-10

Post, J. E., Preston, L. E. et al. (2002). Redefining the corporation. Stakeholder management and organizational wealth. Stanford: Stanford University Press.

Schäfer, M. (1999). Medienmacht macht Medienpolitik. Baden-Baden.

Senate of Canada (2006). Standing senate committee on transportation and communications. Final report on the Canadian news media, Vol. 1 and 2. Ottawa.

\section{Regulatory choices in Communication Governance}

MICHAEL LATZER

\section{Governance as modified research perspective}

The growing use of governance concepts in the communication field indicates a modified research perspective that stresses the importance of institutions in communication policy research, and extends the traditional focus on national government in two directions:

(1) Horizontally, it includes the role of private actors in regulation, the remix of state, and private contributions in communications regulation;

(2) Vertically, it incorporates the multi-level character of regulation, the interplay of national regulation with international, supranational, regional, and local regulation.

Both extensions are important in order to assess recent changes in communication regulation triggered by liberalization and globalization, to grasp the changing and diminishing role of nation states, and to advise policy makers on their regulatory choices between different modes of regulation in convergent markets.

This paper focuses on the regulatory part of governance, defined as intentional constraints on market players. Further, it centers on the growing horizontal extension of government in communications, which is indicated by the increasing incidence of self- and co-regulation, summarized in this paper as alternative modes of regulation ${ }^{1}$. These less formalized means of regulation are not new phenomena in communications regulation. However, empirical research shows that there is a grow- 
ing reliance on such alternative forms of regulation, which are carried out partly, or even entirely, by private regulatory institutions (see Latzer, Just, Saurwein, and Slominsky, 2006; PCMLP, 2004; Schulz and Held, 2004). They are gaining importance at all levels of multi-level governance regimes, and their application is encouraged by political institutions, for instance by the European Commission (see COM, 2001: 428; COM, 2002: 278). Early applications of self- and co-regulation in the communications sector have been predominantly in technical areas and in mediacontent regulation. The greatest reliance on the latter form of regulation within the communications sector can be found in the regulation of print media (see Suhr, 1998; Nordenstreng, 1999), whereas in telecommunications and broadcasting there has always been a stronger reliance on the statutory legal basis and state actors. However, a sharp increase in selfregulation occurred in the 1990s, triggered by the Internet boom. Many single-issue institutions have been founded that are mainly active in expost enforcement measures and in rule making. They usually intervene after problems have occurred and lack strict powers of sanction (see Latzer, Just, Saurwein and Slominsky, 2006).

\section{Regulatory choice as institutional choice}

Growing reliance on alternative modes of regulation not only raises the question of why alternative regulation is introduced, but also on how to decide on the adequate mix of state and alternative regulation from a public-policy perspective.

Regarding the first question, two ideal-type explanations can be distinguished: Private actors are involved in public regulation as makeshift solution or as ideal solution to regulatory problems. It is a makeshift solution if traditional state regulation fails, for example in the case of transborder regulatory problems, when political actors do not have much option but to apply alternative modes of regulation. Otherwise, if nation states have an effective choice between different regulatory forms, self- and co-regulation may be chosen as an ideal solution. The reasons are the expected advantages over state regulation from a public-policy point of view, for example better know-how within the industry, reduced regulatory cost, faster decisions, and more flexible solutions ${ }^{2}$. Alongside these incentives from a public-policy perspective, the major incentive from an industry point of view for a voluntary introduction of selfregulation is to pre-empt state regulation. Accordingly, self-regulation is rather introduced and effectively enforced in areas where governments have the potential to impose state regulation. In other words, 'carrot and stick' strategies will work if the public stick capacity is high, if governments can convincingly 'threaten' to use 'big guns' (command-and- 
control regulations) if the industry does not solve regulatory problems by means of self-regulation (see Ayres and Braithwaite, 1992: $19 \mathrm{ff}$.).

From a public-policy point of view, self- and co-regulation cannot completely replace traditional state intervention. Nevertheless, alternative modes of regulation may be an effective way to complement state regulation. State intervention might only be needed as a temporary and supplementary remedial action (see Gunningham and Sinclair, 1999). The effectiveness and efficiency of regulation depends to a large extent on the interplay between the different forms of regulation on the continuum between state and market.

The question of how to find an adequate mix can be conceptualized as part of a multistage regulatory choice process. The plurality of public and private norm-setting actors and a plurality of norms, ranging from classical command-and-control-regulations (laws) to various forms of 'soft law' and voluntary agreements, are preconditions for regulatory choice (see Schuppert, 2005: 398). The institutional choices regarding the adequate regulatory arrangement cannot be applied across the board for the whole communications sector, but need to be applied on a case-bycase basis for any specific regulatory problem. A rough guideline for the systematic search for a suitable regulatory institutional arrangement, which builds on theoretical reasoning and experiences with various modes of regulation, is summarized in Figure 1. It is structured by consecutive questions, which are to be discussed in order to choose the regulatory arrangements. Policy makers may use it either for ex-ante assessments of regulatory problems at issue, or for ex-post evaluations of already existing policy solutions. Because the primary interest of this analysis is in the changing role of the state, the guideline centers on choices regarding the institutional dimension of regulatory mechanisms, which shows by whom (actors) and how (processes) regulation is carried out, and not on the substantive dimension, which asks what is being regulated (e.g., access, prices) ${ }^{3}$.

As a first step, it is to be decided whether market intervention is deemed necessary at all. A list of regulatory objectives of communications policy, including both cultural and economic goals, makes it possible to systematically discuss the need for market intervention ${ }^{4}$. Regulation theories, in particular normative theories of regulation, prove helpful in this respect.

After the identification of the guiding objectives and the decision on the necessity of market intervention, it has to be clarified whether there is a capacity to act, that is, if the state is in a position to choose between different regulatory forms. The state's ability to choose between regulatory mechanisms could be high on national level but low on the international level, and it could be high in norm setting but low in sanctioning. 
What regulatory objectives are at stake?

Are market interventions necessary to achieve these objectives?

- Cultural and economic objectives

- Theories of regulation

$\checkmark$ If interventions are deemed necessary

How high is the state's capacity to act - the ability to choose between modes of regulation?

Two dimensions to be discussed:

- Within the various levels of a multi-level-governance regime

- Within the regulatory process (norm-setting, ex-antelex-post enforcement, sanctioning)

How big is the need for state intervention?

How appropriate are alternative modes of regulation?

Criteria to be discussed:

- Risk of regulatory failure

- Required intensity of regulatory intervention

- Conflicts between public and private interests

- Differences in market power of the companies involved

- Reputation-sensitivity of the industry to regulation

- Recognized organization that could take over the regulatory task

$$
\checkmark \text { If self- or co-regulation is chosen }
$$

How are alternative modes of regulation instituted?

Success factors to be discussed:

- Operational objectives and clearly defined responsibilities

- Transparent regulatory processes and measurable results

- Defined fall-back scenarios in case of malfunctioning

- Adequate sanction powers

- Periodical reviews and external control by the general public and the state

- Participation possibilities for interested stakeholders

Figure 1. Regulatory choices as institutional choices - a guideline for its systematic discussion.

Hence, the question of the state's options regarding modes of regulation should be discussed systematically on two dimensions: for the various levels of the multi-level governance regime and for the regulatory process, that is, for norm setting, ex-antelex-post enforcement and sanctioning.

If the opportunities for state intervention are low, there might be no other choice (makeshift solution) but to rely on self-regulation and on private actors. Even in this case, the state has some remaining options to control the development. For example, it could initiate and promote alternative regulations and it could take part in self-regulation, either with financial or personal contributions. Otherwise, if the regulatory options are high, then a rational choice (ideal solution) could be made re- 
garding the extent of alternative regulation, which uses the potential benefits from its advantages over state regulation as listed above, and avoids possible disadvantages of alternative regulations, for example a symbolic policy with weak standards, ineffective enforcement and mild sanctions, regulatory capture, and insufficient democratic quality.

The appropriateness of alternative modes of regulation from a publicpolicy perspective can be discussed based on a list of criteria deduced from theoretical and empirical research. Alternative regulation may be appropriate or the necessity for state involvement may be low:

- if the risk of regulatory failure is low;

- if only a low intensity of regulatory intervention is required;

- if there are no strong conflicts between public and private interests;

- if there are no strong differences in market power of the companies involved;

- if the reputation-sensitivity of the regulation to the industry is high;

- if there is an already recognized organization that could take over the regulatory task.

Some examples illustrate the application of the criteria listed ${ }^{5}$. Risks of regulatory failure are high, for instance, if it results in detrimental effects on the functioning of the infrastructure, or if it entails high economic cost, as in the case of spam mail. For the regulation of market transparency, the risk of failure is rather low. The intensity of regulatory intervention can be considered as high if there are existential effects on market players involved, as in the example of interconnection regulations. For market transparency measures it can be assessed as low. The reputationsensitivity to regulations can be evaluated by taking a look at the effects of non-compliance with these regulations. If the non-compliance to a regulation (e. g., regarding consumer protection) results in a loss of reputation and consequently in falling sales figures, then the reputation-sensitivity can be considered to be high.

Regarding the applicability of this checklist, it should be kept in mind that it will not always be possible to deal with all criteria, and sometimes an assessment may lead to contradictory results regarding the choice of regulatory mechanisms. In the case of spam, for example, the risk of regulatory failure is high and at the same time the market is characterized by high reputation-sensitivity. While the former indicates the need for stronger state involvement, the latter indicates the appropriateness of self- and co-regulation. Hence, a balanced mix of state and alternative modes of regulation might be the result of an evaluation that also takes into account the interplay between criteria and the degree of intensity of each particular criterion. 
After the decision on the use of alternative modes of regulation, some choices remain to be made regarding their institutional specifics. From a public interest perspective, there are several success factors to be assessed (see Campbell, 1999). For example, defined fallback-scenarios in the case of malfunctioning, transparent regulatory processes, periodic reviews, options for stakeholder participation, and adequate sanctions.

\section{Concluding remarks}

This paper centered on regulatory choices as institutional choices. It took full account of the changed research perspective of governance and recent developments in the convergent communications sector, for example the growing reliance on self- and co-regulation. Various theoretical and empirical research results on communications governance, in particular on different modes of state and alternative regulation, were bundled in a rough guideline, which is intended to assist policy-makers either in ex-ante assessments of upcoming regulatory problems or in the expost evaluation of policy choices regarding the institutional regulatory arrangements. It goes without saying that any specific regulatory choice in the end remains a political decision, that there are no one-size-fits-all solutions, and that the guideline is not a technocratic formula that can mechanically be applied. Further empirical and comparative research will make it possible to gradually refine the guideline, thus contributing to strengthening the link between communication policy research and policymaking, often being criticized as too weak.

\section{Notes}

1. The paper builds on Latzer, Just, Saurwein and Slominsky (2002, 2003, 2006); Just, Latzer and Saurwein (2007).

2. For potential advantages and disadvantages see Boddewyn (1988); Ayres and Braithwaite (1992); Ogus (1995); Campbell (1999); NCC (2000).

3. For an analysis of regulatory choice that centers on the substantive dimension, see Schuppert (2006: $395 \mathrm{ff}$.).

4. For a structured overview of regulatory goals in the convergent communications sector, see Latzer, Just, Saurwein and Slominski (2002: 105).

5. For a systematic application of this check list on selected regulatory topics (interconnection, market transparency, spam) see Latzer, Just, Saurwein, and Slominski (2002: 152 ff.); Just, Latzer, and Saurwein (2007).

\section{References}

Ayres, I. and Braithwaite, J. (1992). Responsive regulation. New York/Oxford: Oxford University Press. 
Boddewyn, J. J. (1988). Advertising self-regulation and outside participation. New York: Quorum.

Campbell, A. J. (1999). Self-regulation and the media. Federal Communications Law Journal, 51(3), 711-771.

Gunningham, N. and Sinclair, D. (1999). Integrative regulation. A principle-based approach to environmental policy. Law and Social Inquiry, 24(4), 853-896.

Just, N., Latzer, M., and Saurwein, F. (2007). Communications governance: Entscheidungshilfe für die Wahl des Regulierungsarrangements am Beispiel Spam. In P. Donges (Ed.), Von der Medienpolitik zur Media Governance? Köln: Halem (forthcoming).

Latzer, M., Just, N., Saurwein, F., and Slominski, P. (2002). Selbst- und Ko-Regulierung im Mediamatiksektor. Wiesbaden: Westdeutscher Verlag.

Latzer, M., Just, N., Saurwein, F., and Slominski, P. (2003). Regulation remixed: Institutional change through self and co-regulation in the mediamatics Sector. Communications and Strategies, 50(2), 127-157.

Latzer, M., Just, N., Saurwein, F., and Slominski, P. (2006). Institutional variety in communications regulation. Classification scheme and empirical evidence from Austria. Telecommunications Policy, 30(2), 152-170.

NCC - National Consumer Council (2000). Models of self-regulation. An overview of models in business and the professions. London: NCC. Available at http:// www.ncc.org.uk/pubs/pdf/models_self_regulation.pdf

Nordenstreng, K. (1999). European landscape of media self-regulation. In: OSCE Office of the Representative on Freedom of the Media (Ed.). Freedom and Responsibility Yearbook 1998/99 (pp. 169-185). Vienna: OSCE.

Ogus, A. (1995). Rethinking self-regulation. Oxford Journal of Legal Studies, 15(1), 97-108.

PCMLP (2004). Self-regulation of digital media converging on the Internet: Industry codes of conduct in sectoral analysis. Research Report for the European Commission Oxford: PCMLP. Available at: http://www.selfregulation.info/iapcoda/0405iapcode-final.pdf.

Schulz, W. and Held, T. (2004). Regulated self-regulation as a form of modern government. Luton: John Libbey Publishing.

Schuppert, G. F. (2005). Governance im Spiegel der Wissenschaftsdisziplinen. In G. F. Schuppert (Ed.), Governance-Forschung. Vergewisserung über den Stand und Entwicklungslinien. (pp. 371-469). Baden-Baden: Nomos.

Suhr, O. (1998). Europäische Presse-Selbstkontrolle. Baden-Baden: Nomos.

\section{The state as a key success factor for Self-Regulation? Empirical evidence in brief}

MATTHIAS KÜNZLER

\section{Introduction}

The necessity of the state's involvement in self-regulation is a controversial issue in the debate about Governance. As Puppis (earlier in this section) mentioned, the role of the state varies across the six domains of media governance, but there are hardly any empirical studies about the question whether a state's involvement is a key success factor for self- 
regulation. By focusing on three domains of media regulation, namely processes, content, and organizations, some answers will be formulated.

What follows is a secondary analysis of two empirical studies, comparing forms of self- and co-regulation in the broadcasting sector in different western states (Jarren et al., 2002; Puppis et al., 2004). The cases were selected so as to include as broad a spectrum of different forms of self-regulation (SR) and co-regulation (CR) as possible. Document analysis and expert interviews were chosen as research methods. The advantages of these two qualitative methods are their openness and flexibility, which allow discovering new aspects not taken into consideration in existing theories, the possibility to take into account a small number of cases, and their ability to make a step in the direction of theorybuilding (Deacon et al., 1999). The interviewees were professionals from self-regulatory organizations, broadcasting companies, and representatives from regulatory agencies, ministries and researchers. Laws, codes of practice, and secondary literature about the organizations under study were analyzed. The case studies were updated by the author in 2006 . The following presentation of some of the research results is conducted by comparing four dimensions of forms of co- and self-regulation: The types of media co- and self-regulation are responsible for, the role of the state, the rationales for implementing these forms of governance, and the assessment of self- and co-regulation by the interviewees.

\section{Content regulation}

In the domain of content regulation, co-regulation is the most frequent form (see Table 1).

In all cases, co-regulation was introduced for three main reasons. To ensure the media's independence from the state, to be able to review fictional programming before dissemination, and to adjust regulation flexibly to societal change. As an additional reason for introducing coregulation, a shift in the political paradigm in the direction of the state's withdrawal was raised in Canada and New Zealand. Co- and self-regulation are thought to better suit the new paradigm.

Non-statutory regulation is assessed in an ambivalent way by the experts interviewed. The enforcement of rules and the sanctioning of noncompliance are said to operate effectively in the cases of co-regulation. However, this aspect is criticized in the case of self-regulation. This also seems to be the reason for substituting a self-regulation code by coregulation in Italy. Also negatively assessed is the aspect that non-statutory content regulation through self- or co-regulation is only based on complaints and that no positive content requirements can be established. 
Table 1. Self- and co-regulatory mechanisms in five countries.

\begin{tabular}{|c|c|c|c|}
\hline Country & Description & SR/CR & responsibility \\
\hline Australia & $\begin{array}{l}\text { Broadcasters associations develop } \\
\text { codes of practices which have to be } \\
\text { accredited by the regulator (ACMA). } \\
\text { The ACMA monitors the compliance } \\
\text { with complaint handling. In case of } \\
\text { multiple breaches it can tighten } \\
\text { broadcaster's license or implement new } \\
\text { regulations. }\end{array}$ & CR & $\begin{array}{l}\text { Broadcasting } \\
\text { and internet }\end{array}$ \\
\hline New Zealand & $\begin{array}{l}\text { The regulator (BSA) can develop codes } \\
\text { of practice itself or delegate it to the } \\
\text { industry. The codes developed by the } \\
\text { sector must be accredited and } \\
\text { overviewed every five years by BSA. }\end{array}$ & CR & Broadcasting \\
\hline Canada & $\begin{array}{l}\text { The private broadcasters established a } \\
\text { self-regulation organization (CBSC) } \\
\text { which developed Codes of practice. } \\
\text { CBSC committed to maintain certain } \\
\text { demands of the regulation authority } \\
\text { (CRTC), whereas CRTC included parts } \\
\text { of CBSC's codes into the license of } \\
\text { some private broadcasters. }\end{array}$ & $\begin{array}{l}\text { SR (in } \\
\text { part) }\end{array}$ & Broadcasting \\
\hline Germany & $\begin{array}{l}\text { Private broadcasting TV stations } \\
\text { founded the self-regulation } \\
\text { organization FSF. Its mission is to } \\
\text { review fictional programming for the } \\
\text { protection of minors. A commission } \\
\text { of the regulation authorities supervises } \\
\text { the norms defining the protection of } \\
\text { minors and accredited the FSF. }\end{array}$ & CR & Broadcasting \\
\hline Italy & $\begin{array}{l}\text { Two self-regulation organizations } \\
\text { concerning TV for minors exist } \\
\text { (Comitato dei Attazione del Codice dei } \\
\text { Regolamentazione Convenzionale TV } \\
\text { e Minori, Comitato dei Controlle TV } \\
\text { e Minori). Since } 2002 \text { the first one is a } \\
\text { form of co-regulation. }\end{array}$ & $\begin{array}{l}\text { SR and } \\
\text { CR }\end{array}$ & Broadcasting \\
\hline
\end{tabular}

Note: Own description, source: ACMA (2006), BSA (2006), Comitato (2005), FSF (2006), media laws, expert interviews.

\section{Regulation of processes}

Process regulation deals with the establishment of rules for journalistic work processes within media organizations, and for the ways in which information is presented. This kind of regulation is done through developing (ethical) codes of practice for journalistic work and for the presen- 
tation of information, and through the implementation of sanctions in case the code is breached. In most European countries, Press or Media Councils are responsible for this industry-wide. In the case of an assumed code-breach, readers or viewers can file a complaint. It is also possible that a single media organization regulates the processes only for its own organization, something which is normally done by public service broadcasters (for this aspect see Schade and Künzler, 2006). Press and media councils are self-regulated in all cases with the exception of Denmark, and they are often not only responsible for the press but also for radio, television, and the contents distributed on the Internet (Sonninen and Laitila, 1995; Appelquist-Schmidlechner, 2001).

In our research project, we took a detailed look at media councils in Denmark (Pressencevnet), Sweden (Pressens Opinionsnämnd) and Finland (Julkisen Sanan Neuvosto). They are interesting cases because Nordic states have a long tradition in media councils, and because the cases of Denmark and Sweden are different from most other countries. In Denmark, the state established the Danish press council by law (Media Liability Act) in 1992 and some of the Council's members are appointed by the Ministry of Justice. This form was not found in any other country. Another special form of Press Council exists in Sweden. Complaints must first be filed to a Press Ombudsman (Allmänhetens Pressombudsman) which then decides if a complaint will be referred to the Press Council.

Three main rationales for introducing self-regulation are given by all interviewees. Firstly, the threat of statutory regulation and the industry's will to prevent this. (In Denmark the industry failed to achieve this, since the different private actors were not able to agree on founding a council.) Secondly, the assumption that self-regulation could include higher practical relevance. Finally, press councils are dealing with media ethics; a matter which is difficult to cover by law.

Overall, press and media councils are assessed positively in the cases examined. Especially the media's independence from the state and the acceptance by the regulated industry are looked upon favorably by the interviewees. However, the possibility of sanctioning non-compliance is assessed controversially. Normally, media councils can enforce the publication of a reprehension. While the majority of the interviewees assesses this measure as sufficient, some wish for additional sanctioning, for example monetary fines.

\section{Regulation of organizations}

In the domain of regulating organizations, forms of non-statutory regulation are prevailing for the regulation of public service broadcasting. 
An internal board is not only responsible for an organization's compliance with regulations, but also for the internal formulation and enforcement of rules, and sanctioning of its non-compliance. The cases of organizational regulation examined are the BBC Board of Governors (UK) (called BBC Trust as of 2007), RTÉ Authority (Ireland), ORFStiftungsrat (Austria), and the Rundfunkräte of the ARD-members SWR, WDR, MDR (Germany). In each of these cases the state participates in different ways. On the one hand, law delegates responsibility to these boards for monitoring compliance with statutory regulations, for handling program complaints, and for ensuring to maintain quality standards (e. g., through setting internal guidelines). On the other hand, the members of the board are partly appointed by governmental bodies or their formation is regulated by law (especially Germany and Austria regulate in detail which societal groups need to be incorporated). At the same time, the boards are not only responsible for regulating the organization but also for strategic decisions. Because of the state's involvement, these boards are co-regulated, but since regulation is designated to a single media organization and not to a self-regulation organization which is responsible for the whole industry, it can be named 'enforced self-regulation' (Ayre and Braithwaite, 1992).

Hence, the main rationale for implementing co-regulation through an internal board is seen in the public service's independence from the state. In Germany and Austria it is mentioned that the BBC was viewed as an example.

The self-regulation of public service broadcasters is assessed ambivalently. The possibility to include representatives of different societal groups in the boards is positively evaluated. But the disadvantage is an assumed insufficient enforcement of rules, which is believed to stem from the double role as a strategic board and a self-regulation organization on the one hand, and in the boards' lacking independence of the organization on the other hand.

\section{Conclusion}

The results presented provide us some answers to the question of whether or not the participation of the state in self-regulation is a key success factor. The fundamental advantage of self- and co-regulation is increased independence from the state. This may ensure the media's independence better than statutory regulation. However, the state remains important. In the field of process regulation, self-regulation is positively assessed but was introduced due to the threat of statutory regulation. In contrast, in the domain of content regulation, self-regulation is negatively assessed, while involvement of the state through co- 
Table 2. Types of process, content, and organization regulation.

\begin{tabular}{|c|c|c|c|}
\hline & \multicolumn{3}{|l|}{ Regulation of $[\ldots]$} \\
\hline & Processes & Content & Organization \\
\hline Type of media & $\begin{array}{l}\text { press, broadcast- } \\
\text { ing, Internet }\end{array}$ & broadcasting, internet & $\begin{array}{l}\text { public service } \\
\text { broadcasting }\end{array}$ \\
\hline Role of the state & $\begin{array}{l}\text { mainly self-regula- } \\
\text { tion }\end{array}$ & mainly co-regulation & co-regulation \\
\hline \multirow[t]{3}{*}{$\begin{array}{l}\text { Reasons of } \\
\text { implementation }\end{array}$} & $\begin{array}{l}\text { threat of statutory } \\
\text { regulation }\end{array}$ & $\begin{array}{l}\text { ensure media's indepen- } \\
\text { dence from state }\end{array}$ & $\begin{array}{l}\text { ensure media's } \\
\text { independence } \\
\text { from state }\end{array}$ \\
\hline & $\begin{array}{l}\text { higher practical } \\
\text { expertise }\end{array}$ & $\begin{array}{l}\text { review fictional program- } \\
\text { ming before dissemination }\end{array}$ & \multirow{2}{*}{$\begin{array}{l}\mathrm{BBC} \text { as a role } \\
\text { model in Ger- } \\
\text { man-speaking } \\
\text { countries }\end{array}$} \\
\hline & $\begin{array}{l}\text { dealing with media } \\
\text { ethics }\end{array}$ & flexibility & \\
\hline \multirow[t]{3}{*}{ Assessment } & \multirow{2}{*}{$\begin{array}{l}\text { mainly positive, } \\
\text { especially inde- } \\
\text { pendence from the } \\
\text { state and accept- } \\
\text { ance by the regu- } \\
\text { lated industry }\end{array}$} & $\begin{array}{l}\text { mainly positive assessment } \\
\text { of } C R\end{array}$ & \multirow{3}{*}{$\begin{array}{l}\text { ambivalent } \\
\text { positive: possi- } \\
\text { bility to in- } \\
\text { clude repre- } \\
\text { sentatives of } \\
\text { different } \\
\text { societal groups } \\
\text { negative: insuf- } \\
\text { ficient enforce- } \\
\text { ment of rules }\end{array}$} \\
\hline & & $\begin{array}{l}\text { mainly negative assessment } \\
\text { of SR } \\
\text { in part criticized: no posi- }\end{array}$ & \\
\hline & $\begin{array}{l}\text { possibilities of } \\
\text { sanctioning are } \\
\text { assessed as } \\
\text { controversial }\end{array}$ & le & \\
\hline
\end{tabular}

regulation is seen as positive. In the domain of organization regulation, co-regulation is not completely looked upon favorably either.

Apart from the question whether the state should be involved, the interviews have shown that there are four other key success factors:

(1) Independence of self-regulation organizations from the regulated industry

(2) Acceptance of self-regulation by the regulated companies and professionals

(3) Sufficient funding and personnel resources

(4) Clear definition of the procedures and goals of the self-regulation organization and its transparency to the public

With regard to the main question of this contribution, this means that the direct involvement of the state through co-regulation is not necessarily a mandatory key success factor of governance. Apart from the state, 
there are some other key success factors. Whether the state should be involved in self-regulation depends rather on the domains of governance. However, the state still remains important at least through its ability to threaten the implementation of statutory regulation.

\section{References}

ACMA (Australian Communications and Media Authority) (2006). About ACMA. Available (consulted 11 November 2006) at: http://www.acma.gov.au/ACMAINTER. 1048806:LANDING::pc=ACMA,tlp=ACM.

Appelquist-Schmidlechner, K. (2001). Selbstkontrolle der Medien im Prozess der Qualitätssicherung. In H. H. Fabris and F. Rest (Eds.): Qualität als Gewinn. (pp. 169179). Innsbruck: Studien Verlag.

Ayres, I. and Braithwaite, J. (1992). Responsive regulation. Transcending the deregulation debate. New York/Oxford: Oxford University Press.

BSA (Broadcasting Standards Authority) (2006). Codes and standards. Available (consulted 11 November 2006) at: www.bsa.govt.nz/broadcastingact.htm

Comitato di attuazione del codice dei regolamentazione convenzionale TV e minori (2005). Codici a Confronto. Una Comparazione tra Codici die Autoregolamentazione in Materia die TV e Minori. Available (consulted 11 November 2006) at: http: //www.comitatotveminori.it/pdf/codici.pdf

Deacon, D., Pickering, M., Golding, P., and Murdock, G. (1999). Researching communications. A practical guide to methods in media and cultural analysis. London: Arnold.

FSF (Freiwillige Selbstkontrolle Fernsehen e.V.) (2006). Programmprüfung. Available (consulted 11 November 2006) at: http://www.fsf.de/fsf2/pruefung/pruefung.htm

Jarren, O., Weber, R. H., Donges, P., Dörr, B., Künzler, M., and Puppis, M. (2002). Rundfunkregulierung. Leitbilder, Modelle und Erfahrungen im internationalen Vergleich: Eine sozial- und rechtswissenschaftliche Analyse. Zürich: Seismo.

Puppis, M., Künzler, M., Schade, E., Donges, P., Dörr, B., Ledergerber, A., and Vogel, M. (2004). Selbstregulierung und Selbstorganisation. Unveröffentlichter Schlussbericht zuhanden des Bundesamtes für Kommunikation (BAKOM). Zürich: IPMZ.

Schade, E. and Künzler, M. (2006). Qualitätssicherung durch Selbstorganisation? Das Controlling-Dilemma bei öffentlichen Rundfunkorganisationen. In S. Weischenberg, W. Loosen, and M. Beuthner (Eds.), Medien-Qualitäten: Öffentliche Kommunikation zwischen ökonomischem Kalkül und Sozialverantwortung (pp. 245262). (Schriftenreihe der Deutschen Gesellschaft für Publizistik- und Kommunikationswissenschaft, Band 33.) Konstanz: UVK.

Sonninen, P. and Laitla, T. (1995). Press councils in Europe. In: K. Nordenstreng (Ed.), Reports on media ethics in Europe (pp. 3-22). Tampere: Department of Journalism and Mass Communication University of Tampere.

\section{Co-Regulation in European Union member states}

THORSTEN HELD

\section{Aim of the study}

Regulation in general and regulation within the media sector in particular has to face the fact that new technologies and internationalization 
have led to widespread and fundamental changes. These developments, which are often described as a change of former industrial societies to so-called information societies, represent a challenge for the regulating states. Traditional regulation, though successful and efficient in the past, might be unsuitable under changed circumstances. The role of the state needs to be redefined. In some countries, the state has included nonstate regulation in its regulatory concept. The present study focuses on the following questions:

(1) Which models of co-regulation do already exist within the member states and selected non-EU States when it comes to media regulation?

(2) How can efficiency and effectiveness of co-regulatory measures be judged?

(3) What are the requirements of European Law that have to be kept in mind when implementing models of co-regulation?

\section{Reasons for shifting to new forms of regulation}

When it comes to regulation, different concepts can be found. While command-and-control regulation may be seen as a traditional form of regulation, co-regulation seems to be a rather new approach that consists of more than merely a combination of state regulation and self-regulation. The growing interest in new regulatory concepts can be traced back to findings on failures of traditional regulation. Studies have pinpointed several reasons for the failure of traditional 'command-and-control' regulation (see Schulz and Held, 2004: 11) such as the fact that traditional regulation ignores the interests of the regulated objects (Mayntz, 1979: 55 ff.; Baldwin and Cave, 1999) and that initiative, innovation, and commitment cannot be imposed by law (Mayntz, 1987) ${ }^{2}$, the increasing knowledge gap of the regulating state (Ukrow, 2000), globalization ${ }^{3}$ as well as difficulties in intervening in autonomous social systems (e.g., Mayntz and Scharpf, 1995).

\section{Definition of 'co-regulation'}

Within the understanding of the study, co-regulation is a specific combination of state and non-state regulation. Based on an analysis of earlier studies, the present study develops the following definition of co-regulation (HBI and EMR, 2006: 35). The non-state component of the regulatory systems includes: 
(1) The creation of specific organizations, rules or processes

(2) To influence decisions by persons or, in the case of organizations, decisions by or within such entities

(3) As long as this is performed, at least partly, by or within the organizations or parts of society whose members are addressees of the (non-state) regulation.

The non-state part has to be regulation in itself. There has to be some influence on decisions of persons or, in the case of organizations, decisions of, or within, such entities. In addition, this influence has to be exerted not just case-by-case. In most countries, influence is exerted by non-state organizations setting codes, rating content, or supervising the industry. With regard to the link between a non-state regulatory system and state regulation, one can speak of co-regulation if the following criteria are met:

(1) The system is established to achieve public policy goals targeted at social processes.

(2) There is a legal connection between the non-state regulatory system and the state regulation.

(3) The state leaves discretionary power to a non-state regulatory system.

(4) The state uses regulatory resources to influence the outcome of the regulatory process (to guarantee the fulfillment of the regulatory goals).

One main criterion is the existence of a legal connection between state regulation and non-state regulation. This link can be a state act, but also a contract or guidelines set by the state regulator. Another criterion is that the state uses regulatory resources such as power or money to influence the outcome of the non-state regulatory process. In most countries, this resource is the certification of non-state organizations or codes. Other instruments may be the appointment of members of non-state organizations and financing of non-state organizations. However, the state has to leave discretionary power to the non-state regulation. Otherwise, there would be no real division of work between the state side and the non-state side.

\section{Existing models}

Different models of co-regulation exist in the member states of the European Union. However, they do not apply to all types of media. While a tradition of pure self-regulation exists in the press sector, co-regulatory 
systems are in place in the sectors of broadcasting and film regulation, in some states even in the field of internet regulation. When it comes to the goals of regulation, co-regulatory measures are mainly used for the protection of minors and the protection of consumers (the latter by means of advertising rules).

\section{Youth protection}

In the area of youth protection, two different kinds of approaches exist: In some states, there is a non-state organization that rates content and decides whether the respective content is suitable for minors in specific age brackets. Examples of this approach exist in Germany and Austria. For the broadcasting sector in Germany, it is the task of an Einrichtung der Freiwilligen Selbstkontrolle to classify content and to ensure the enforcement of rules. Furthermore, it may make exemptions to the watershed regulation for the broadcasting of movies, which had been given a rating by the non-state body for movies in the past. However, instruments are in place to regulate non-state regulation, of which the most important is that Einrichtungen der Freiwilligen Selbstkontrolle need certification (for further details see HBI and EMR, 2006: $48 \mathrm{ff}$.; Schulz and Held, 2006: 58).

In the areas of movies and computer games, non-state bodies are also responsible for age classification (suitable for all children and adolescents, six years and older, twelve years, sixteen years, or not suitable for children and adolescents). Here, another tool of state involvement can be found. Members of the examination boards are nominated by state authorities. The examination boards include permanent representatives of the state authorities (for further details see HBI and EMR, 2006: $54 \mathrm{ff}$.; Schulz and Held, 2006: 57). In Austria, the state authorities of the Bundesländer (states) that are responsible for age classification as a rule follow recommendations of the non-state Jugendmedienkommission (JMK, Commission for the Protection of Minors against Improper Media Contents). As in the above-mentioned German system, the state gains some influence on the non-state regulatory process by appointing members of the non-state body. Representatives of the federal government and the states are members of the JMK (for further details see HBI and EMR, 2006: $43 \mathrm{ff}$.).

In other member states, the rating is done by the companies themselves based on coding forms developed by non-state organizations (as in the Netherlands, in the United Kingdom, in Italy, and in Slovenia). In some of these member states, it is also the task of non-state organizations to enforce compliance with the codes. A brief description of the system in the Netherlands may illustrate this type of co-regulation. Non- 
state regulation is performed by the Nederlands Instituut voor de Classificatie van Audiovisuele Media (NICAM, the Dutch Institute for the Classification of Audiovisual Media). The classification system called Kijkwijzer (in the double meaning of Watch wiser or Viewing guide) was developed by independent experts and launched in 2001 by NICAM. It introduces a uniform classification system for movies, TV, video, and DVD. In this system, classification is done by the broadcasters, and film and video companies themselves. Specially trained employees use a coding form to describe the content. A Kijkwijzer computer program then determines the classification of a given production. By using special pictograms, broadcasters, film and video companies inform the viewers of the classification. As long as a provider is a member of NICAM, NICAM is responsible for supervision of compliance including the handling of complaints. NICAM was accredited by a decision of the government. In addition, the state authority responsible for regulating the media was entrusted with the task of performing so-called meta supervision of NICAM (for further details see HBI and EMR, 2006; Schulz and Held, 2006).

\section{Protection of consumers by means of advertising rules}

Concerning the protection of consumers by means of advertising rules, regulatory systems exist within member states where non-state bodies set codes and enforce compliance with these codes (as in the United Kingdom, in the Netherlands, and in Greece). In the United Kingdom, for example, the state regulator, the Office of Communications (Ofcom), has contracted out the setting up of the advertising codes and their enforcement to different non-state organizations.

The Communications Act of 2003 requires the state regulator Ofcom to consider the desirability of promoting and facilitating the development and use of effective forms of self-regulation. Responsibility for advertising content regulation (but not frequency or sponsorship) was assigned to the non-state Advertising Standards Authority Broadcast (ASA(B)) and Broadcast Committee of Advertising Practice (BCAP).

Ofcom contracted out the function to set advertising codes to the BCAP. Any changes of the codes require the consent of Ofcom. The powers of handling and resolving complaints of breaches of the BCAP Codes were contracted out to ASA(B) (for further details see HBI and EMR, 2006: 90).

In some member states, non-state organizations offer a 'pre-clearance' of advertisements before these advertisements are published (in France for example). In France, the state regulator Conseil supérieur de l'audiovisuel (CSA, Higher Council in Audiovisual Media) applies ex-post con- 
trol. Ex-ante control is performed by a non-state body, the Bureau de vérification de la publicité (BVP, Advertising Verification Bureau). However, CSA can overrule the BVP's decisions (for further details see HBI and EMR, 2006).

\section{Requirements of European law}

As mentioned above, the planned changes of the 'Television Without Frontiers Directive' will allow the use of co-regulation to transpose the directive's rules into national law. Apart from this, the Treaty establishing the European Community leaves to the national authorities the choice of form and methods to transpose directives into national law. Therefore, it is generally possible to transpose European directives into state law by means of co-regulation.

However, the European Court of Justice has stipulated certain requirements that have to be met (see HBI and EMR, 2006: $156 \mathrm{ff}$.):

- One requirement is that national rules have to be transparent, clear, and precise (see ECJ, 361/88, para. 24; C-220/94, para. 10).

- Another requirement is that a directive has to be implemented in an effective and binding manner (see ECJ, C-59/89, para. 34; C-80/92, para. 20; C-151/94, para. 18; C-296/01, para. 54; C-415/01, para. 21).

These requirements do not mean that a complete transformation of the directive into state law is necessary. For example, agreements between state and non-state organizations are sufficient (see Calliess and Ruffert 2007: Art. 249 EGV, para. 52).

\section{Results of an impact assessment}

To judge the effectiveness of co-regulatory approaches an impact assessment was undertaken in the study. ${ }^{4}$ One principal finding of the impact assessment ${ }^{5}$ is that there is no reason to assume that co-regulatory models as defined within this study are generally insufficient to implement European directives (neither with regard to the effectiveness of regulation nor the legal requirements). However, some requirements have to be met:

- First, there have to be sufficient incentives for the industry to participate.

- Second, the different regulatory cultures have to be kept in mind when designing a co-regulatory system. While the broadcasting industry, for example, seems to welcome co-regulation as a form of deregulation, 
the internet industry is more skeptical about it because there is more state intervention than in pure self-regulation.

- Third, the existing regulatory path has to be taken into account. The chosen co-regulatory approach has to fit in the overall regulatory framework in the given country.

- Fourth, effective and graduated sanctions have to be at the disposal of the regulators in place.

- Finally, there has to be safety net in case non-state regulation should fail.

Another finding of the impact assessment is that a great many of the existing co-regulatory approaches lack transparency although transparency is both a requirement set by the European Court of Justice and a democratic value protected by the national constitutions.

In addition, some systems are designed as closed shops. Interest groups such as consumer groups are seldom included in the systems. Notwithstanding these problems that can be overcome, co-regulatory approaches are capable of fulfilling objectives such as the protection of minors and the protection of consumers by means of advertising regulation. Systems that exist for example in Germany, in the Netherlands, and in the United Kingdom may serve as role models for the design of coregulatory approaches.

\section{Notes}

1. In May 2007, European Parliament and Council agreed on an amended proposal, stating that "member states shall encourage co- and/or self-regulatory regimes at national level".

2. In addition, the state has to act before a trajectory has been laid out if the state wants to influence the outcome of a process ('preventive state') (see Schuppert, 2001: $201 \mathrm{ff}$.).

3. This facilitates international 'forum shopping' to evade national regulations. In addition, globalization has created an additional problem. While the economic system now tends primarily toward multi-national or even global structures, legal regulation is still mainly the preserve of the nation-states. Structures of non-governmental law now have to be taken into account by nation-states (Teubner, 1997: $763 \mathrm{ff})$.

4. Besides desk research, an expert survey was conducted. For the methods of the study, see HBI and EMR, 2006: $3 \mathrm{ff}$.

5. For further details see HBI and EMR, 2006: $108 \mathrm{ff}$.

\section{References}

Baldwin, R. and Cave, M. (1999). Understanding regulation: Theory, strategy, and practice. Oxford: Oxford University Press. 
Calliess, C. and Ruffert, M. (Eds.) (2007). Kommentar des Vertrages über die Europäische Union und des Vertrages zur Gründung der Europäischen Gemeinschaft: EUVI $E G V$. Neuwied et al.: Luchterhand.

Hans-Bredow-Institut (HBI) and Institut für Europäisches Medienrecht (EMR) (2006). Study on co-regulation measures in the media sector. Final report. Brussels: European Commission. Available at: http://ec.europa.eu/comm/avpolicy/docs/ library/studies/coregul-final-report.pdf.

Mayntz, R. (1979). Regulative Politik in der Krise?. In J. Matthes (Ed.) Sozialer Wandel in Westeuropa: Verhandlungen des 19. Deutschen Soziologentages (pp. 55-81).

Berlin: Campus-Verl.

Mayntz, R. (1987). Politische Steuerung und gesellschaftliche Steuerungsprobleme Anmerkungen zu einem theoretischen Paradigma. In T. Ellwein, J. J. Hesse, R. Mayntz, and F. W. Scharpf (Eds.), Jahrbuch zur Staats- und Verwaltungswissenschaft, Vol. 1 (pp. 89-110). Baden-Baden: Nomos-Verl.-Ges.

Mayntz, R. and Scharpf, F. W. (Eds.) (1995). Gesellschaftliche Selbstregelung und politische Steuerung. Frankfurt am Main et al.: Campus-Verl.

Schulz, W. and Held, T. (2004). Regulated self-regulation as a form of modern government. Eastleigh: John Libbey Pub.

Schulz, W. and Held, T. (2006). Together they are strong? Co-regulatory approaches for the protection of minors within the European Union. In U. Carlsson (Ed.). Regulation, awareness, empowerment: Young people and harmful media content in the digital age (pp. 49-65). Göteborg: The International Clearinghouse on Children, Youth and Media, Nordicom/Göteborg University.

Schuppert, G. F. (2001). Das Konzept der regulierten Selbstregulierung als Bestandteil einer als Regelungswissenschaft verstandenen Rechtswissenschaft. Die Verwaltung, special issue Regulierte Selbstregulierung 4, 201-252.

Teubner, G. (1997). The king's many bodies: The self-deconstruction of law's hierarchy. Law and Society Review, 31, 763-787.

Ukrow, J. (2000). Die Selbstkontrolle im Medienbereich in Europa. München: Jehle Rehm. 